\title{
Enhanced T cell activation in Plasmodium falciparum malaria-infected human immunodeficiency virus-1 patients from Mozambique
}

\author{
Helena Chavale ${ }^{1,2}$, Joanna Reis Santos-Oliveira ${ }^{3}$, Alda Maria Da-Cruz ${ }^{3 /+}$, Sonia Enosse ${ }^{1,2}$ \\ ${ }^{1}$ Instituto Nacional de Saúde, Ministério da Saúde, Maputo, Moçambique ${ }^{2}$ Laboratório de Biologia Molecular, \\ Hospital Central de Maputo, Maputo, Moçambique ${ }^{3}$ Laboratório Interdisciplinar de Pesquisas Médicas, \\ Instituto Oswaldo Cruz-Fiocruz, Ministério de Saúde, Rio de Janeiro, RJ, Brasil
}

\begin{abstract}
Human immunodeficiency virus (HIV)-1 infection has an important impact on malaria. Plasmodium falciparum and HIV-1 co-infected patients $(\mathrm{Pf} / H I V)$ present with a high degree of anaemia, enhanced parasitaemia and decreased $C D 4^{+} T$ cell counts, which increase the risk of developing severe malaria. In addition, infection with either Pf or HIV-1 alone causes extensive immune activation. Our hypothesis was that lymphocyte activation is potentiated in $\mathrm{Pf} / H I V$ co-infected patients, consequently worsening their immunosuppressed state. To test this hypothesis, $22 \mathrm{Pf} /$ HIV patients, 34 malaria patients, 29 HIVIAIDS patients and 10 healthy controls without malaria or HIV/acquired immune deficiency syndrome (AIDS) from Maputo/Mozambique were recruited for this study. As expected, anaemia was most prevalent in the $\mathrm{Pf} / \mathrm{HIV}$ group. A significant variation in parasite density was observed in the $\mathrm{Pf} / \mathrm{HIV}$ co-infected group (110-75,000 parasites $/ \mu \mathrm{L})$, although the median values were similar to those of the malaria only patients. The $\mathrm{CD}^{+}$T cell counts were significantly lower in the $\mathrm{Pf} / H I V$ group than in the HIV/AIDS only or malaria only patients. Lymphocyte activation was evaluated by the percentage of activation-associated molecules [CD38 expression on $C D 8^{+}$and human leukocyte antigen-DR expression on $C D 3^{+} T$ cells]. The highest $C D 38$ expression was detected in the $\mathrm{Pf} / \mathrm{HIV}$ co-infected patients (median $=78.2 \%)$. The malaria only (median $=50 \%$ ) and HIV/AIDS only (median $=52 \%$ ) patients also exhibited elevated levels of these molecules, although the values were lower than those of the Pf/HIV co-infected cases. Our findings suggest that enhanced T-cell activation in co-infected patients can worsen the immune response to both diseases.
\end{abstract}

Key words: malaria/HIV-AIDS - cellular activation - Plasmodium - co-infection - CD4 ${ }^{+} \mathrm{T}$ cells - Mozambique

As leading causes of morbidity and mortality, malaria and human immunodeficiency virus (HIV)/acquired immune deficiency syndrome (AIDS) are two of the most important diseases in Africa (Idemyor et al. 2007). Plasmodium falciparum-associated HIV-1 (Pf/HIV) infection has been described in many sub-Saharan Africa countries and data from these countries account for most of the available clinical data regarding this co-infection (Chalwe et al. 2009, Davenport et al. 2010, Kiyingi et al. 2010, Mills et al. 2010, Serna-Bolea et al. 2010, Naniche et al. 2011). A relevant issue in malaria-endemic regions is the identification of HIV/AIDS patients among suspected cases of acute malaria (Mills et al. 2010, Serna-Bolea et al. 2010). Furthermore, HIV-1 infection is a risk factor for receiving an incorrect diagnosis of malaria (Berg et al. 2008). Thus, surveillance health programs should invest considerable effort to minimise the misdiagnosis of febrile diseases.

Financial support: IOC internal founds, CAPES

$\mathrm{HC}$ is a student from the Post Graduate Program in Health Sciences/ Tropical Medicine, FIOCRUZ/INS-MISAU (General Cooperation Agreement Brazil-Mozambique). JRSO is a PhD student from PGMT and was sponsored by CNPq and FAPERJ. AMC is a research fellow from CNPq and FAPERJ (JCNE).

+ Corresponding author: alda@ioc.fiocruz.br

Received 24 March 2012

Accepted 16 August 2012
In Mozambique (Mz), malaria is endemic throughout the country and is most prevalent after the rainy season, which lasts from December-April. Malaria and HIV/AIDS are the most important causes of mortality with rates of $29 \%$ and $27 \%$, respectively (INS/INE/ICF 2010). According to the World Malaria Report (WHO 2011), approximately four million estimated cases and 3,300 deaths due to malaria were reported in $\mathrm{Mz}$ during 2010. Considering that $11.5 \%$ of population is estimated to be infected with HIV-1, the overlap of these dually endemic diseases increases for the risk of $P f$ and HIV-1 co-infection. Recently, a study of 136 HIV-1 infected individuals from southwest Mz revealed that $5.1 \%$ were also infected with $P f$ (Naniche et al. 2011).

There is evidence that $P f / \mathrm{HIV}$ co-infection enhances the spread of both $P f$ malaria and HIV-1 infection and may also influence the severity of the clinical manifestations of these diseases. Indeed, HIV infection has been considered an important risk factor for severe Pf malaria (Grimwade et al. 2004, Chalwe et al. 2009). Increased Plasmodium parasitaemia is most likely related to the impairment of parasite control caused by HIV-1-related immunosuppression (Whitworth et al. 2000, Patnaik et al. 2005). Patients with low $\mathrm{CD}^{+} \mathrm{T}$ cell counts of less than 350 cells $/ \mathrm{mm}^{3}$ are more likely to exhibit complications arising malaria (Cohen et al. 2005, Mouala et al. 2009). Moreover, HIV-1 infection is associated with an increased prevalence of anaemia in Pf malaria (Otieno et al. 2006, Davenport et al. 2010). Malaria can also affect HIV-1 infection. HIV/AIDS pa- 
tients with malaria can exhibit a transitory reduction in the number of $\mathrm{CD} 4^{+} \mathrm{T}$ cells, which may be partially reversible after successful antimalarial therapy (Van Geertruyden et al. 2006a). A causal relationship between malarial episodes and a decline in $\mathrm{CD}^{+} \mathrm{T}$ cell counts in HIV-1 patients remains to be established (Mermim et al. 2006). Acute malaria elevates the HIV viral load (VL), which in turn can enhance the risk for HIV transmission (Kublin et al. 2005). In addition, Plasmodium antigens lead to strong cellular activation (Worku et al. 1997) which may facilitate de novo HIV-1 infection and replication (Froebel et al. 2004). The preference of HIV-1 for infecting activated memory CD4 ${ }^{+}$ $\mathrm{T}$ lymphocytes can increase cell death (Grossman et al. 2002). Consequently, it is possible that, in co-infected patients, $P f$-specific T-cell clones are depleted by HIV-1 during each malaria episode (Whitworth \& Hewitt 2005, Mermim et al. 2006). Therefore, these factors can decrease the immune response to both diseases and contribute to HIV disease progression.

Cell activation is one of the crucial mechanisms in the pathogenesis of both malaria (Worku et al. 1997) and HIV-1/AIDS (Douek et al. 2009). The release of pro-inflammatory cytokines due to increased $\mathrm{T}$ cell activation during acute malaria has been implicated in the clinical complications and contributes to a disruption in the balance of effector/regulatory immune state (Ayimba et al. 2011, Davenport et al. 2012). In HIV-1/AIDS, it is well established that the VL is directly associated with $\mathrm{CD} 8^{+}$ $\mathrm{T}$ cell activation (Benito et al. 2004). However, the mechanism by which the association of these two pathogens can impact the immunopathogenesis of malaria/HIVAIDS remains under discussion. Few studies addressing the compromised immunological state have been reported for malaria/HIV-AIDS co-infection (Naniche et al. 2011) and, to our knowledge, none has investigated the consequences of cellular activation in the immunosuppression state. Because both $P f$ and HIV alone can cause immune activation, our hypothesis was that lymphocyte activation is potentiated in co-infected patients. As a consequence, activation-induced lymphocyte death could aggravate the immunosuppressed state of co-in- fected patients. For test this hypothesis, we evaluated the severity of anaemia, Plasmodium parasite density (PD) and impairment of the cellular immune response in malaria/ HIV-1 co-infected adults from southwest Mz.

\section{PATIENTS, MATERIALS AND METHODS}

Study population - All patients were recruited from the Polana Caniço Health Centre (PCHC) in Maputo, the capital of Mz, between January-December 2010. PCHC is an outpatient health care centre situated in a suburb of Maputo and provides medical care for patients from three neighbourhoods: Maxaquene, Polana Caniço and Hulene. Maputo is an area of stable malaria transmission, with a rate of $\geq$ one case per 1,000 inhabitants and a high percentage of individuals have a past history of malaria (73-76\%). HIV-1 prevalence in $\mathrm{Mz}$ is $11.5 \%$, affecting approximately 9,000 individuals each year (INE 2009). In PCHC, the malaria care service is responsible for the diagnosis of malaria and the dispensation of antimalarial drugs according to the malaria management guidelines established by Ministry of Health (MISAU)/Mz. This health centre also attends to and counsels HIV/AIDS patients.

A cross-sectional study was performed in which $P f /$ HIV-1 co-infected patients were recruited from patients presenting with clinical malaria. A total of 99 recruited participants were placed into the following four groups: $22 \mathrm{Pf} / \mathrm{HIV}, 29$ patients infected with HIV-1 only (HIV-1/ AIDS), 38 infected patients with $P f$ only (malaria) and a group of 10 subjects who were negative for both malaria and HIV-1 [healthy controls (HC)]. The demographic characteristics of the study subjects are shown in Table. Their ages ranged from 20-75 years (mean age - 38 \pm 12.2 ; median - 37 years) and the majority of the participants were female $(59.2 \%)$. Laboratory exams were performed to diagnose anaemia, malaria and HIV/AIDS according to the MISAU/Mz guidelines. The levels of haemoglobin (Hg) and white blood cells (WBC) were determined by a complete haemogram exam. The results were expressed as $\mathrm{g} / \mathrm{dL}$ for $\mathrm{Hg}$ and $10^{3} / \mu \mathrm{L}$ for WBC.

The patients were screened for malaria with a qualitative rapid diagnostic test (RDT) (SD Malaria Antigen Pf BIOLINE kit, Standard Diagnosis Inc, Giheung-ku,

TABLE

Demographic characteristics of study population

\begin{tabular}{lcccc}
\hline & & & \multicolumn{2}{c}{ Distribution per gender } \\
\cline { 3 - 4 } Cases/controls & Cases & Age (years) & Male (40.7\%) & $\begin{array}{c}\text { Female }(59.2 \%) \\
(\%)\end{array}$ \\
\hline Pf/HIV co-infected & $(\mathrm{n})$ & mean $\pm \mathrm{SD}^{a}$ (median) & 36.4 & 63.6 \\
Malaria & 22 & $38.2 \pm 15(34)$ & 31.6 & 68.4 \\
HIV/AIDS & 38 & $39.4 \pm 13(39)$ & 51.7 & 48.3 \\
Healthy controls $^{b}$ & 29 & $37 \pm 10.8(36)$ & 50 & 50 \\
\hline
\end{tabular}

$a$ : no statistical difference among the four groups; $b$ : subjects without malaria or human immunodeficiency virus (HIV)-1/acquired immune deficiency syndrome (AIDS); Pf/HIV: Plasmodium falciparum and HIV-1 co-infected patients; SD: standard deviation. 
Republic of South Korea) to detect the histidine rich protein II of $P f$ in blood samples. After their consent, patients with a RDT positive test were screened for HIV according to the Mozambican National protocol. This protocol consists of a sequential algorithm of two immunochromatographic rapid tests. All individuals were first screened with the Determine HIV-1/2 test (Abbott Laboratories Co, Ltd, Tokyo Japan). All specimens that were reactive by this screening assay were further tested using the HIV test, Uni-gold ${ }^{\mathrm{TM}}$ Recombigen ${ }^{\circledR}$ (Trinity Biotech PLC, Bray Ireland). Patients over 18 years of age, who were infected with HIV-1, who did not receive antiretroviral (ARV) therapy and who had a positive RDT for malaria were recruited for the co-infected study group. Pregnancy tests were used to identify pregnant women that were excluded from the study. Patients who were positive for only malaria or HIV-1 infection were enrolled into either the malaria or HIV/AIDS groups, respectively. Volunteers who were negative for both tests comprised the HC group. HIV/AIDS patients were referred to the counselling program.

Determination of Plasmodium PD - The Plasmodium species identification and PD were determined in RDT positive patients. To determine the malarial parasite density, the finger was pricked and a thick blood smear was made. The blood smears were stained with Giemsa stain and were examined under oil-immersion microscope by trained laboratory technicians until had greater than 500 WBC or 500 parasites. The $P f$ PD was calculated after the actual leukocyte count was taken into consideration and was determined by the following formula: $\mathrm{PD}$ $=$ (number of parasites/number WBC on each slide) $\mathrm{x}$ WBC per $\mathrm{mL}$ from each patient $\mathrm{x} 10^{3}$. The results were expressed as the number of parasites $/ \mu \mathrm{L}$.

Determination of absolute $T$ cells counts and lymphocyte activation levels - To quantify the number of $\mathrm{CD}^{+} \mathrm{T}$ and $\mathrm{CD} 8^{+} \mathrm{T}$ lymphocytes in the blood, BD Tritest $^{\mathbb{R}}$ monoclonal antibodies specific for CD4, CD8 and CD3 conjugated to FITC, PE and PerCP, respectively and the BDTrue Count ${ }^{\circledR}$ reagent kit were used according to the manufacturer's instructions (BD Biosciences, Franklin Lakes, NJ, USA). In parallel, the blood cells were also stained with anti-CD8 FITC/anti-CD38 PE and anti-CD3 FITC/anti-human leukocyte antigen (HLA)-DR PE monoclonal antibodies (BD Simultest ${ }^{\mathrm{TM}}$, BD Biosciences, San Jose, CA, USA).

The samples were acquired using a FACSCalibur ${ }^{\circledR}$ flow cytometer (BD, USA) and analysed by Multiset ${ }^{\mathbb{B}}$ software for CD4 counting, whereas phenotypic analysis was performed with by CellQuest ${ }^{\mathrm{TM}}$ software. Both software programs were obtained from BD Biosciences. The experiments were performed at the centre of reference for AIDS diagnosis at the MISAU/Mz [Laboratory of Molecular Biology and Hematology at Maputo Central Hospital, Laboratory of Parasitology and Immunology National Institutes of Health (INS)] and in Brazil [Laboratory of Molecular Immunology and AIDS, Oswaldo Cruz Institute, Oswaldo Cruz Foundation (IOC/ FIOCRUZ), Ministry of Health].
Although the validated marker of $\mathrm{CD} 8^{+} \mathrm{T}$ cell activation is the co-expression of CD38 and HLA-DR, activated cells were identified by detecting $\mathrm{CD} 38$ on $\mathrm{CD} 8^{+}$ $\mathrm{T}$ cells and HLA-DR on $\mathrm{CD}^{+} \mathrm{T}$ cells. These molecules were used as surrogates for the validated marker (Douek et al. 2009). HLA-DR positivity was determined on the $\mathrm{CD}^{+} \mathrm{T}$ cell population and CD38 positivity was determined on the $\mathrm{CD} 8^{+} \mathrm{T}$ cell population, inside the gate previously established for the $\mathrm{CD}^{+} \mathrm{T}$ cell population. The results were expressed as the percentage of HLA-DR on $\mathrm{CD}^{+}$and $\mathrm{CD} 38$ on CD8 ${ }^{\text {high }} \mathrm{T}$ cells.

Statistical analysis - The values were expressed as the median and interquartile range (IQR). The MannWhitney $U$ test and the non-parametric Spearman's test were used for the comparison and correlation analysis of the data, respectively (GraphPad Prism, version 4.0, San Diego, CA, USA). The differences were considered significant when $\mathrm{p}<0.05$.

Ethics - The study was approved by the Mozambican Ethical Committee (National Bioethics Committee for Health), under protocol 194/CNBS and written informed consent was obtained from all participants.

\section{RESULTS}

Impact of malaria-associated HIV-1/AIDS on the severity of anaemia - Hg levels were used to evaluate the degree of anaemia (Fig. 1). Co-infected patients had lower $\mathrm{Hg}$ levels (median $=10.1 \mathrm{~g} / \mathrm{dL}$, IQR $-8.4-11.2 \mathrm{~g} / \mathrm{dL}$ ) than did patients with $P f$ only (median $=12 \mathrm{~g} / \mathrm{dL}, \mathrm{IQR}-10.2$ $13.3 \mathrm{~g} / \mathrm{dL}, \mathrm{p}<0.001$ ) or HIV-1/AIDS only (median $=11.4$ $\mathrm{g} / \mathrm{dL}, \mathrm{IQR}-11.2-12.6 \mathrm{~g} / \mathrm{dL}, \mathrm{p}<0.05$ ) or the HC group (median $=12.8$, IQR $-11.5-14 \mathrm{~g} / \mathrm{dL} \mathrm{n}=10, \mathrm{p}<0.01$ ) (Fig. 1). No significant differences were observed between the malaria and HIV-1/AIDS only patients or between the $\mathrm{HC}$ and the malaria or HIV-1/AIDS only patients.

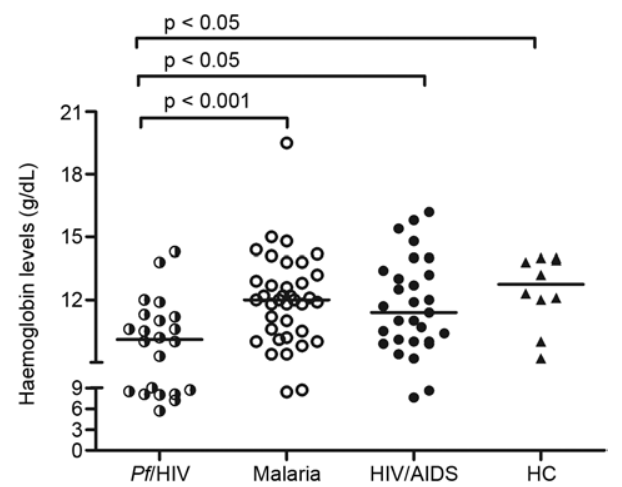

Fig. 1: anaemia severity estimated by haemoglobin concentration in Plasmodium falciparum and human immunodeficiency virus (HIV)-1 co-infected ( $P f / \mathrm{HIV}$ )/acquired immune deficiency syndrome (AIDS) patients. $P f / H I V$ co-infected patients (black and white circles), Pf malaria only patients (white circles) and HIV-1/AIDS only patients (black circles) and healthy controls (HC) without malaria or HIV-1/ AIDS (solid triangles). Each point represents one subject. The horizontal bars express median. 


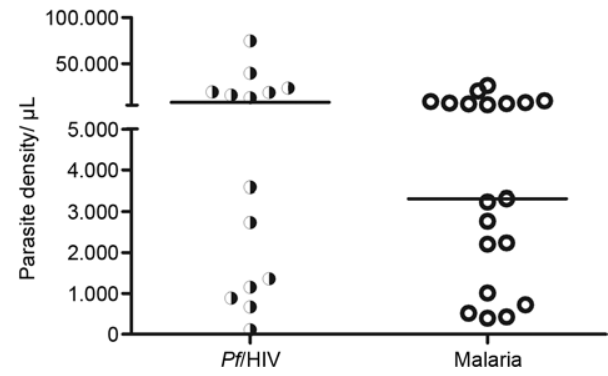

Fig. 2: determination of Plasmodium falciparum $(P f)$ parasite density (PD) in human immunodeficiency virus (HIV)-1 co-infected patients. The blood smears were stained with Giemsa stain and the parasites were counted until the observed fields had reached greater than 500 white blood cells or 500 parasites. The PD was calculated according to the formula shown in Patients, Materials and Methods section, considering individual actual leukocytes counts per mL. Black and white circles: $P f / \mathrm{HIV}$ co-infected patients; white circles: $P f$ malaria only patients. Each point represents one subject. The horizontal bars express median. There was no statistic difference between groups.

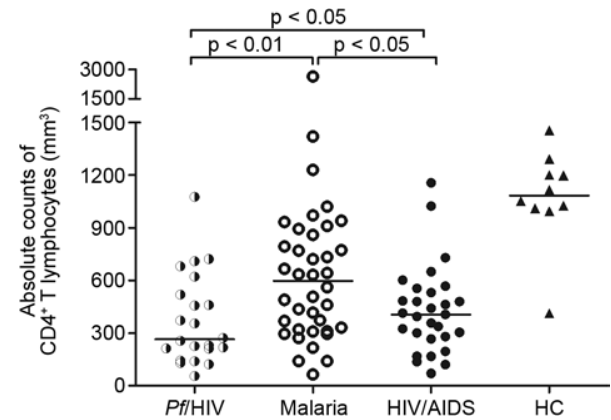

Fig. 3: evaluation of immunosuppressed state in malaria associated human immunodeficiency virus (HIV)-1/acquired immune deficiency syndrome (AIDS) patients by the absolute number of $\mathrm{CD}^{+} \mathrm{T}$ lymphocytes. Black and white circles: Plasmodium falciparum (Pf)/ HIV co-infected patients; black circles: HIV-1/AIDS only patients; solid triangles: healthy controls (HC) without malaria or HIV-1/ AIDS; white circles: $P f$ malaria only patients. Each point represents one subject. The horizontal bars express median.
$P D$ in $P f / H I V$ - Fifty-nine patients were positive for malaria by RDT; however the PD quantification was possible for only 33 of these patients (Fig. 2). There was no significant difference in the PD of the co-infected patients (median $=8,326$ parasites $/ \mu \mathrm{L}, \mathrm{IQR}-1,087-20,357$ parasites $/ \mu \mathrm{L}, \mathrm{n}=14$ ) compared to the malaria only patients (median $=3,308$ parasites $/ \mu \mathrm{L}, \mathrm{IQR}-1,013-8,050$ parasites $/ \mu \mathrm{L}, \mathrm{n}=19$ ). Although, high levels of parasitaemia were observed in both groups, a wider variation in the parasite load was observed in the co-infected patients $(110-75,000$ parasites $/ \mu \mathrm{L})$.

Malaria-associated HIV-1 co-infected patients present with low $\mathrm{CD}^{+} \mathrm{T}$ lymphocytes levels - To determine whether the malaria association may influence the immunosuppression caused by HIV-1 infection, the blood levels of $\mathrm{CD}^{+} \mathrm{T}$ lymphocytes were quantified (Fig. 3). Significantly lower $\mathrm{CD}^{+} \mathrm{T}$ values were observed in the $\mathrm{Pf} / \mathrm{HIV}$ co-infected patients (median = 265 cells $/ \mathrm{mm}^{3}$, IQR $-195-545$ cells $\left./ \mathrm{mm}^{3}, \mathrm{n}=22\right)$ than in the HIV-1/AIDS patients (median $=406$ cells $/ \mathrm{mm}^{3}$, IQR-274-543 cells $\left./ \mathrm{mm}^{3}, \mathrm{n}=29, \mathrm{p}<0.05\right)$. These levels were also lower than those observed in the malaria patients $\left(\right.$ median $=597$ cells $/ \mathrm{mm}^{3}$, IQR $-318-868$ cells $/$ $\mathrm{mm}^{3}, \mathrm{n}=38, \mathrm{p}<0.01$ ) or the HC group (median $=1,084$ cells $/ \mathrm{mm}^{3}$, IQR - 1,007-1,224 cells $/ \mathrm{mm}^{3}, \mathrm{n}=10, \mathrm{p}<$ $0.001)$. In addition, HIV-1/AIDS patients also exhibited reduced $\mathrm{CD}^{+} \mathrm{T}$ cell levels compared to malaria patients $(\mathrm{p}<0.05)$ or HC $(\mathrm{p}<0.001)$. A positive correlation between $\mathrm{CD} 4^{+} \mathrm{T}$ cell counts and $\mathrm{Hg}$ levels were observed when all groups were evaluated together $(r=$ $0.40, \mathrm{p}<0.001)$ (data not shown).

The association of malaria plus HIV-1 enhances the $T$ cell activation state - To determine whether $P f$ infection may contribute to augmentation $\mathrm{T}$ cell activation in $\mathrm{Pf} / \mathrm{HIV}$ co-infected patients, the percentage of activated $\mathrm{CD}^{+}$and $\mathrm{CD}^{+} \mathrm{T}$ cells was measured by flow cytometry using the expression of the activation-associated membrane molecules HLA-DR and CD38, respectively.
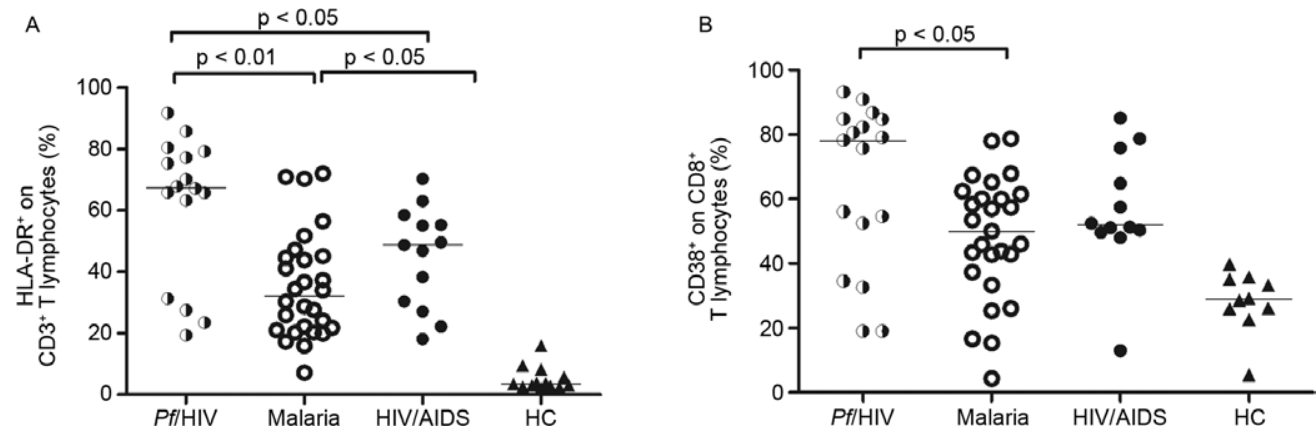

Fig. 4: T lymphocyte activation state in Plasmodium falciparum and human immunodeficiency virus (HIV)-1 co-infected (Pf/HIV)/acquired immune deficiency syndrome (AIDS) patients. Black and white circles: $P f / H I V$ co-infected patients; black circles: HIV-1/AIDS only patients; solid triangles: healthy controls (HC) without malaria or HIV-1/AIDS; white circles: Pf malaria only patients. The flow cytometry analysis of the percentage of human leukocyte antigen-DR on $\mathrm{CD} 3^{+} \mathrm{T}(\mathrm{A})$ and $\mathrm{CD} 38$ on $\mathrm{CD} 8^{+} \mathrm{T}(\mathrm{B})$ cells were determined in lymphocyte gates as described in Patients, Materials and Methods section. Each point represents one subject. The horizontal bars express median. 
$P f / \mathrm{HIV}$ co-infected patients presented with the highest levels of lymphocyte activation compared to the other groups (Fig. 4A). The levels of HLA-DR ${ }^{+}$on the $\mathrm{CD}^{+} \mathrm{T}$ cells from the $P f / \mathrm{HIV}$ patients were significantly higher $($ median $=67.5 \%, \mathrm{IQR}-39.3-77.8 \%, \mathrm{n}=17)$ than on $\mathrm{T}$ cells from the malaria only patients (median $=32.1 \%$, IQR - 21.2-45\%, $\mathrm{n}=29, \mathrm{p}<0.001$ ) or the HIV-AIDS only patients (median $=48.8 \%, \mathrm{IQR}-28.8-57 \%, \mathrm{n}=13, \mathrm{p}<$ $0.05)$. Notably, the malaria patients also exhibited high

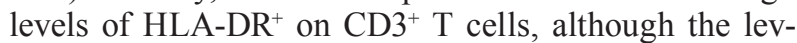
els were lower than those observed on cells from HIV-1/ AIDS patients $(\mathrm{p}<0.05)$.

With regard to the percentage of $\mathrm{CD} 38^{+}$on $\mathrm{CD} 8^{+} \mathrm{T}$ lymphocytes (Fig. 4B), the state of cellular activation was also more elevated in the $P f / \mathrm{HIV}$ co-infected group (median $=78.2 \%, \mathrm{IQR}-43.5-85 \%, \mathrm{n}=17)$ than in the malaria only patients (median $=50 \%$, IQR $-37.3-61.5 \%$, $\mathrm{n}=29, \mathrm{p}<0.01$ ). However, no significant difference was observed with regard to the HIV-1/AIDS only group $($ median $=52 \%$, IQR $-49.8-73.1 \%, \mathrm{n}=13)$. Elevated levels of activation were observed in the malaria and HIV-1/AIDS only patients and there were no difference between these groups. As expected, the lowest levels of cellular activation were observed in the HC group $\left(\mathrm{HLA}^{-D R}{ }^{+}\right.$, median $=3.4 \%, \mathrm{IQR}-2.6-7 \%$ and $\mathrm{CD} 38^{+}$, median $=28.9 \%$, IQR - 25-35.3\%).

To determine if the parasitaemia is involved in the cellular activation of $P f / \mathrm{HIV}$ co-infected patients, a correlation analysis was performed. For this analysis 17 Pf/HIV co-infected patients and 29 malaria only patients were studied. No significant correlation between $\mathrm{PD}$ and the percentage of HLA-DR ${ }^{+}$and $\mathrm{CD} 38^{+}$on the $T$ lymphocytes was observed for either group. By contrast, a negative correlation was observed between the $\mathrm{CD}^{+} \mathrm{T}$ cell counts and HLA-DR on the $\mathrm{CD}^{+} \mathrm{T}$ lymphocytes when malaria, HIV-AIDS, Pf/HIV co-infected patients and the $\mathrm{HC}$ group were considered together $(r=-0.70, p<0.01)($ Fig. 5).

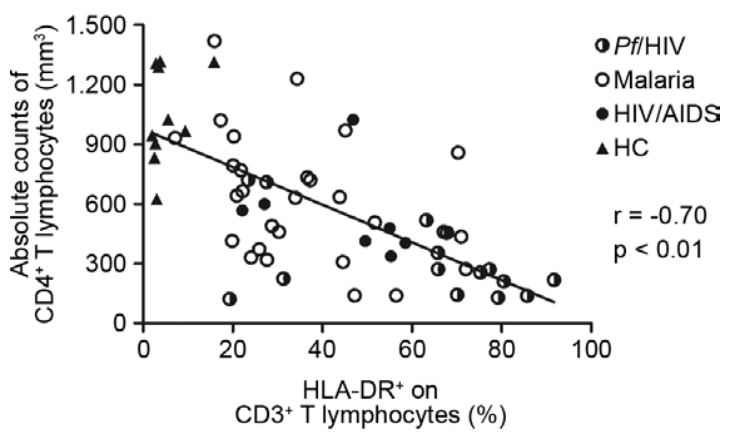

Fig. 5: correlation between $\mathrm{CD} 4^{+} \mathrm{T}$ cell counts and human leukocyte antigen (HLA)-DR ${ }^{+}$on $\mathrm{CD}^{+} \mathrm{T}$ lymphocytes in Plasmodium falciparum and human immunodeficiency virus (HIV)-1 co-infected ( $P f \mid$ HIV)/acquired immune deficiency syndrome (AIDS) patients. Black and white circles: $P f / H I V$ co-infected patients; black circles: HIV-1/ AIDS only patients; solid triangles: healthy controls (HC) without malaria or HIV-1/AIDS; white circles: $P f$ malaria only patients.

\section{DISCUSSION}

Most of the available data regarding malaria-associated HIV-AIDS is related to the consequences of HIV infection on the degree of anaemia, Plasmodium PD and $\mathrm{CD}^{+} \mathrm{T}$ lymphocyte counts in $P f$ malaria patients, particularly in sub-Saharan Africa countries (Whitworth et al. 2000, Cohen et al. 2005, Patnaik et al. 2005, Mouala et al. 2009, Davenport et al. 2010). However, the impact of both infections on the state of immune cellular activation is largely unknown. This study investigated whether co-infection had a synergistic effect on the immune activation induced by Plasmodium or HIV-1 alone. Our results suggest that $P f$ malaria enhances T lymphocyte activation in individuals concomitantly infected with HIV-1. This phenomenon can affect immune effector function and may constitute an additional mechanism that contributes to the pathogenesis of malaria-associated HIV-1/AIDS disease.

Anaemia is a major symptom of malaria and can be caused by several mechanisms, including the destruction of infected erythrocytes, antibody-mediated lysis, hypersplenism, impaired erythropoiesis and cytokines (Idemyor et al. 2007, Haldar \& Mohandas 2009, Quintero et al. 2011). In a previous study, $10 \%$ of adults with severe malaria had Hg levels of $7 \mathrm{~g} / \mathrm{dL}$ or less, which is much lower than expected for a healthy individual (WHO 2000). Moreover, HIV-1 infection itself can also cause anaemia (Belperio \& Rhew 2004) and constitutes an important risk factor for severe malaria in adults (Grimwade et al. 2004, Chalwe et al. 2009). In our study, anaemia was present at a higher degree in $P f / \mathrm{HIV}$ coinfected patients, since they had lower Hg levels than the malaria only patients. This difference does not seem to be related to gender as the percentage of females was higher than males in both groups. In addition, the $\mathrm{Hg}$ concentration and PD are not correlated in the $P f / \mathrm{HIV}$ co-infected patients or the malaria only patients. These results are consistent with other studies of malaria transmission in sub-Saharan Africa areas, such as Cameroon (Nkuo Akenji et al. 2002) and Kenya (Davenport et al. 2010). However, conflicting results regarding anaemia have also been observed in Kenya (Mc Elroy et al. 2000) and Tanzania (Ekval et al. 2001). As has been shown for other conditions, such as malnutrition, ARV drugs use or infection with intestinal parasites, co-infection with HIV and malaria can worsen the anaemic condition, particularly in low income regions.

Immunosuppression caused by HIV infection appears to impair the ability to control the parasitaemia, resulting in an enhancement of the Plasmodium PD (Van Geertruyden et al. 2006b). Despite reports that HIV individuals are more likely to be parasitaemic (Whitworth et al. 2000, Patnaik et al. 2005), there was no significant difference in the parasite load between the $P f / \mathrm{HIV}$ co-infected patients and the malaria only patients is this study. It is important to note that, in our study, the parasitaemia intensity calculation was based on the individual leukocyte count per $\mathrm{mL}$ instead of a fixed number of leukocytes per $\mathrm{mL}$. Notably, a wide range of PD levels was detected in the $P f / \mathrm{HIV}$ co-infected group, varying from $110-75,000$ parasites $/ \mu \mathrm{L}$. 
Depletion of $\mathrm{CD}^{+} \mathrm{T}$ cells is a common consequence of HIV-1 infection (Grossman et al. 2002). However, acute malaria only also reduces the number $\mathrm{CD}^{+} \mathrm{T}$ lymphocytes (Chougnet et al. 1992, Kassa et al. 2006). Among the patients evaluated in this study, the lowest $\mathrm{CD} 4^{+} \mathrm{T}$ values were observed in the co-infected patients. The number of $\mathrm{CD}^{+} \mathrm{T}$ cells in the malaria or HIV-1/AIDS only patients was also lower than in the $\mathrm{HC}$ group. These results suggest a heightened degree of immunosuppression in malaria-associated HIV-1/AIDS. Interestingly, this reduction in $\mathrm{CD}^{+} \mathrm{T}$ cells is transient and the levels of these cells increase after successful antimalarial therapy, although the number of $\mathrm{CD} 4^{+} \mathrm{T}$ cells does not reach the previous counts (Kassa et al. 2006, Van Geertruyden et al. 2006a. Therefore, each episode of acute malaria causes an excess decrease in the $\mathrm{CD} 4^{+} \mathrm{T}$ cell numbers (Mermim et al. 2006), which aggravates the immunosuppressed state. These facts highlight the importance of assessing any malaria-induced disturbances in the laboratory prior to deciding how to manage HIV positive individuals. This approach can avoid the misdiagnosis of ARV failure or even the premature initiation of therapy (Brentlinger et al. 2007). Unfortunately, access to ARV is not yet universal, either in Mz (INSIDA 2009) or in other African countries, whereas antimalarials drugs are currently accessible for the population.

$\mathrm{CD}^{+} \mathrm{T}$ cell counts have been implicated in Plasmodium control (Brentlinger et al. 2007, Idemyor 2007), because these cells are negatively correlated with PD (Withworth et al. 2000, Patnaik et al. 2005). However, we did not observe any association between these parameters, perhaps because of the study sample size. Moreover, because the adult population evaluated in this study is from a stable transmission area, these adults are considered immune and therefore, the level of parasitaemia should be lower than in children from the same area, potentially explaining the lack of correlation between the PD and immunosuppression.

Chronic immune activation is the strongest predictor of the progression rate to AIDS in HIV-1 infected individuals (Douek et al. 2009). Acute malaria infection may also be associated with an enhanced cellular activation state. Co-expression of CD38/HLA-DR on T cell subsets has previously been studied in both HIV-1/AIDS or malaria alone (Hunt et al. 2003, Eggena et al. 2006, Naniche et al. 2011) and immune activation was considered a predictor of treatment failure in malaria patients (Eggena et al. 2006). Malaria infection can present with a pro-inflammatory response and cytokine imbalance (Ayimba et al. 2011, Davenport et al. 2012). In this study, $P f / \mathrm{HIV}$ co-infected patients exhibited the highest percentages of HLA-DR and CD38 on the $\mathrm{CD}^{+}$and $\mathrm{CD}^{+} \mathrm{T}$ lymphocytes, respectively. Indeed, malaria patients had higher percentages of $\mathrm{CD} 38$ on $\mathrm{CD}^{+}$and HLA-DR on $\mathrm{CD}^{+} \mathrm{T}$ cells than did the healthy subjects, confirming previous data that malaria itself contributes to activation (Worku et al. 1997). Although dual-positive CD38/HLA-DR on $\mathrm{CD}^{+} \mathrm{T}$ cells is a more accurate measure of the activation state, when both molecules were analysed separately, they displayed the same profile. Similar to that observed for the $\mathrm{CD}^{+} \mathrm{T}$ counts, the viral or parasite antigens ap- pear to act together to boost cell activation, either directly or by inducing the release of soluble factors. HIV-1 co-infection with other diseases, such as leishmaniasis (Santos-Oliveira et al. 2010), tuberculosis (Rodrigues et al. 2003) or leprosy (Giacoia-Gripp et al. 2011), has previously been demonstrated to increase cellular activation. A previous study conducted in Mz did not identify a significant correlation between the "malaria infection" parameter and the levels of HLA-DR/CD38 on activated $\mathrm{CD}^{+}$and $\mathrm{CD} 8^{+} \mathrm{T}$ cells (Naniche et al. 2011). However, the authors of this study did not compare $P f / \mathrm{HIV}$ coinfected patients to malaria or HIV/AIDS only patients. We cannot exclude the possibility that dual-infected $P f$ HIV patients could be in more advanced stages of HIV/ AIDS and/or have more opportunistic infections, which could contribute to decreased $\mathrm{CD}^{+} \mathrm{T}$ cell counts and increased $\mathrm{T}$ cell activation.

Viral replication is a well-known factor that contributes to lymphocyte activation and is considered a predictor parameter for HIV VL (Benito et al. 2004). Nevertheless, one limitation of our study is that we did not determine the HIV-1 VL, because this assessment is not routinely available for African public health systems (INSIDA 2009). This study did not find a causal relationship between $P f$ PD and T cell activation. However, malarial antigens cannot be ruled out as an important factor for immune activation. Therefore, the role of each infection in this exacerbated activation state and the additional implications for the pathogenesis and management of malaria/HIV-1 co-infection must be clarified. In addition, we did not follow-up the $P f / H I V$ co-infected patients during malaria, their convalescence to evaluate whether the T-cell activation state decreased and achieved the activation levels observed in the malaria or HIV-1/AIDS only patients.

Our results demonstrate that the anaemia, $P f$ parasitaemia and $\mathrm{CD}^{+} \mathrm{T}$ counts profiles of malaria-HIV-1 infected patients from southwest $\mathrm{Mz}$ are similar to those observed in other sub-Saharan Africa studies (Patnaik et al. 2005, Van Geertruyden et al. 2006a, Davenport et al. 2010). Complementary to these studies, our findings suggest that malaria/HIV-1-AIDS association may contribute to enhanced $T$ cell activation in co-infected patients. This phenomenon is of utmost importance because these cells can (i) augment the release of proinflammatory cytokines causing systemic damage and (ii) be more susceptible to die by activation-induced cell death (Kemp et al. 2002). Finally, potential regional differences are expected to occur depending on the malaria endemicity. Additional studies in sub-Saharan Africa countries, including prospective follow-up are of extreme importance to better understand the relationship between malaria and HIV-1 infection and the consequences of these infections on the immunopathogenesis of malaria/HIV-1 co-infection.

\section{ACKNOWLEDGEMENTS}

To Dr Simone Ladeia, for critical reviewing the paper, to the health workers from Polana Caniço Health Centre outpatient unit, for helping recruitment of patients, to Ms. Elisa M Mahanjane, for her helpful secretarial assistance, to the Labora- 
tory of Parasitology and Immunology (INS/MISAU) and to Dr Mariza Morgado (Laboratory of Molecular Immunology and AIDS-IOC/Fiocruz), for allowing the use of the equipment and their technical academic support, and to Dr Ilesh Jani and Dr Wilson Savino (coordinators of PGCS, INS/MISAU, Fiocruz), for their support during the development of this study.

\section{REFERENCES}

Ayimba E, Hegewald J, Ségbéna AY, Gantin RG, Lechner CJ, Agosssou A, Banla M, Soboslay PT 2011. Proinflammatory and regulatory cytokines and chemokines in infants with uncomplicated and severe Plasmodium falciparum malaria. Clin Exp Immunol 166: $218-226$.

Belperio PS, Rhew DC 2004. Prevalence and outcomes of anemia in individuals with human immunodeficiency virus: a systematic review of the literature. Am J Med 116 (Supp1 7A): 27S-43S.

Benito JM, Lopez M, Lozano S, Martinez P, Gonzalez-Lahoz J, Soriano V 2004. CD38 expression on $\mathrm{CD}^{+} \mathrm{T}$ lymphocytes as a marker of residual virus replication in chronically HIV-infected patients receiving antiretroviral therapy. AIDS Res Hum Retroviruses 20: 227-233.

Berg A, Patel S, Langeland N, Blomberg B 2008. Falciparum malaria and HIV-1 in hospitalized adults in Maputo, Mozambique: does HIV-infection obscure the malaria diagnosis? Malar J 7: 252.

Brentlinger PE, Behrens CB, Kublin JG 2007. Challenges in the prevention, diagnosis and treatment of malaria in human immunodeficiency virus infected adults in sub-Saharan Africa. Arch Intern Med 167: 1827-1836.

Chalwe V, Van Geertruyden JP, Mukwamataba D, Menten J, Kamalamba J, Mulenga M, D'Alessandro U 2009. Increased risk for severe malaria in HIV-1-infected adults, Zambia. Emerg Infect Dis 15: 749.

Chougnet C, Tallet S, Ringwald P, Deloron P 1992. Kinetics of lymphocyte subsets from peripheral blood during a Plasmodium falciparum malaria attack. Clin Exp Immunol 90: 405-408.

Cohen C, Karstaedt A, Frean J, Thomas J, Govender N, Prentice E, Dini L, Galpin J, Crewe-Brown H 2005. Increased prevalence of severe malaria in HIV-infected adults in South Africa. Clin Infect Dis 41: 1631-1637.

Davenport GC, Hittner JB, Were T, Ong'echa JM, Perkins DJ 2012. Relationship between inflammatory mediator patterns and anemia in HIV-1 positive and exposed children with Plasmodium falciparum malaria. Am J Hematol 87: 652-658.

Davenport GC, Ouma C, Hittner JB, Were T, Ouma Y, Ong'echa JM, Perkins DJ 2010. Hematological predictors of increased severe anemia in Kenyan children coinfected with Plasmodium falciparum and HIV-1. Am J Hematol 85: 227-233.

Douek D, Roederer M, Koup R 2009. Emerging concepts in the immunopathogenesis of AIDS. Annu Rev Med 60: 471-484.

Eggena MP, Hopkins H, Barugahare B, Okello M, Ssali F, Mugyenyi P, Rosenthal PJ, Cao H, Dorsey G 2006. CD4 T cell activation as a predictor for treatment failure in Ugandans with Plasmodium falciparum malaria. Am J Trop Med Hyg 74: 41-43.

Ekvall H, Premji Z, Bennett S, Bjorkman A 2001. Hemoglobin concentration in children in a malaria holoendemic area is determined by cumulated Plasmodium falciparum parasite densities. Am J Trop Med Hyg 64: 58-66.

Froebel K, Howard W, Schafer JR, Howie F, Whitworth J, Kaleebu P, Brown AL, Riley E 2004. Activation by malaria antigens renders mononuclear cells susceptible to HIV infection and re-activates replication of endogenous HIV in cells from HIV-infected adults. Parasite Immunol 26: 213-217.
Giacoia-Gripp CB, Sales AM, Nery JA, Santos-Oliveira JR, de Oliveira AL, Sarno EN, Morgado MG 2011. Evaluation of cellular phenotypes implicated in immunopathogenesis and monitoring immune reconstitution inflammatory syndrome in HIV/leprosy cases. PLOS ONE 6: e28735.

Grimwade K, French N, Mbatha DD, Zungu DD, Dedicoat M, Gilks CF 2004. HIV infection as a cofactor for severe falciparum malaria in adults living in a region of unstable malaria transmission in South Africa. AIDS 18: 547-554.

Grossman Z, Meier-Schellersheim M, Sousa AE, Victorino RM, Paul WE 2002. CD4 ${ }^{+}$T-cell depletion in HIV infection: are we closer to understanding the cause? Nat Med 8: 319-323.

Haldar K, Mohandas N 2009. Malaria, erythrocytic infection and anemia. Hematology Am Soc Hematol Educ Program 87-93.

Hunt PW, Martin JN, Sinclair E, Bredt B, Hagos E, Lampiris H, Deeks SG 2003. T cell activation is associated with lower CD4 ${ }^{+}$ $\mathrm{T}$ cell gains in human immunodeficiency virus-infected patients with sustained viral suppression during antiretroviral therapy. J Infect Dis 187: 1534-1543.

Idemyor V 2007. Human immunodeficiency virus (HIV) and malaria interaction in sub-Saharan Africa: the collision of two Titans. HIV Clin Trials 8: 246-253.

INE - Instituto Nacional de Estatística 2009. Mortalidade em Moçambique: inquérito nacional sobre as causas de mortalidade, 2007/2008 - relatório preliminar, INE, Moçambique, 100 pp.

INSIDA - Instituto Nacional de Saúde 2009. Inquérito nacional de prevalência, riscos comportamentais e informação sobre o HIV e SIDA em Moçambique, INSIDA, Maryla, 310 pp.

Kassa D, Petros B, Mesele T, Hailu E, Wolday D 2006. Characterization of peripheral blood lymphocyte subsets in patients with acute Plasmodium falciparum and P. vivax malaria infections at Wonji Sugar Estate, Ethiopia. Clin Vaccine Immunol 13: 376-379.

Kemp K, Akanmori BD, Adabayeri V, Goka BQ, Kurtzhals JA, Behr C, Hviid L 2002. Cytokine production and apoptosis among T cells from patients under treatment for Plasmodium falciparum malaria. Clin Exp Immunol 127: 151-157.

Kiyingi HS, Egwang TG, Nannyonga M 2010. Prolonged elevation of viral loads in HIV-1-infected children in a region of intense malaria transmission in Northern Uganda: a prospective cohort study. Pan Afr Med J 7: 11.

Kublin JG, Patnaik P, Jere CS, Miller WC, Hoffman IF, Chimbiya N, Pendame R, Taylor TE, Molyneux ME 2005. Effect of Plasmodium falciparum malaria on concentration of HIV-1-RNA in the blood of adults in rural Malawi: a prospective cohort study. Lancet 365: 233-240.

Mc Elroy PD, ter Kuile FO, Lal AA, Bloland PB, Hawley WA, Oloo AJ, Monto AS, Meshnick SR, Nahlen BL 2000. Effect of Plasmodium falciparum parasitemia density on hemoglobin concentrations among full-term, normal birth weight children in western Kenya. IV. The Asembo Bay Cohort Project. Am J Trop Med Hyg 62: $504-512$.

Mermin J, Lule JR, Ekwaru JP 2006. Association between malaria and CD4 cell count decline among persons with HIV. J Acquir Immune Defic Syndr 41: 129-130.

Mills LA, Kagaayi J, Nakigozi G, Galiwango RM, Ouma J, Shott JP, Ssempijja V, Gray RH, Wawer MJ, Serwadda D, Quinn TC, Reynolds SJ 2010. Utility of a point-of-care malaria rapid diagnostic test for excluding malaria as the cause of fever among HIV-positive adults in rural Rakai, Uganda. Am J Trop Med Hyg 82: 145-147. 
Mouala C, Guiguet M, Houzé S, Damond F, Pialoux G, Viget N, Costagliola D, Le Bras J, Matheron S, FHDH-ANRS CO4 Clinical Epidemiology Group 2009. Impact of HIV infection on severity of imported malaria is restricted to patients with CD4 cell counts $<350$ cells/microl. AIDS 23: 1997-2004.

Naniche D, Letang E, Nhampossa T, David C, Menendez C, Alonso $P$ 2011. Alterations in T cell subsets in human immunodeficiency virus-infected adults with co-infections in southern Mozambique. Am J Trop Med Hyg 85: 776-781.

Nkuo Akenji TK, Ajame EA, Achidi EA 2002. An investigation of symptomatic malaria parasitaemia and anaemia in nursery and primary school children in Buea District Cameroon. Cent Afr J Med 48: 1-4.

Otieno RO, Ouma C, Ong'echa JM, Keller CC, Were T, Waindi EN, Michaels MG, Day RD, Vulule JM, Perkins DJ 2006. Increased severe anemia in HIV-1-exposed and HIV-1-positive infants and children during acute malaria. AIDS 20: 275-280.

Patnaik P, Jere CS, Miller WC, Hoffman IF, Wirima J, Pendame R, Meshnick SR, Taylor TE, Molyneux ME, Kublin JG 2005. Effects of HIV-1 serostatus, HIV-1 RNA concentration and CD4 cell count on the incidence of malaria infection in a cohort of adults in rural Malawi. J Infect Dis 192: 984-991.

Quintero JP, Siqueira AM, Tobón A, Blair S, Moreno A, ArévaloHerrera M, Lacerda MVG, Valencia SH 2011. Malaria-related anaemia: a Latin American perspective. Mem Inst Oswaldo Cruz 106 (Suppl. I): 91-104

Rodrigues DS, Cunha RM, Kallas EG, Salomão R 2003. Distribution of naive/effector $\mathrm{CD} 4^{+} \mathrm{T}$ lymphocytes and expression of $\mathrm{CD} 38$ on $\mathrm{CD} 8^{+} \mathrm{T}$ lymphocytes in AIDS patients with tuberculosis. Braz $J$ Infect Dis 7: 161-165.

Santos-Oliveira JR, Giacoia-Gripp CB, Alexandrino de Oliveira P, Amato VS, Lindoso JÂ, Goto H, Oliveira-Neto MP, Mattos MS, Grinsztejn B, Morgado MG, Da-Cruz AM 2010. High levels of
T lymphocyte activation in Leishmania-HIV-1 co-infected individuals despite low HIV viral load. BMC Infect Dis 10: 358.

Serna-Bolea C, Muñoz J, Almeida JM, Nhacolo A, Letang E, Nhampossa T, Ferreira E, Alonso P, Naniche D 2010. High prevalence of symptomatic acute HIV infection in an outpatient ward in southern Mozambique: identification and follow-up. AIDS 24: 603-608.

Van Geertruyden JP, Mulenga M, Kasongo W, Polman K, Colebunders R, Kestens L, D’Alessandro U 2006a. CD4 T-cell count and HIV-1 infection in adults with uncomplicated malaria. $J$ Acquir Immune Defic Syndr 43: 363-367.

Van Geertruyden JP, Mulenga M, Mwananyanda L, Chalwe V, Moerman F, Chilengi R, Kasongo W, Van Overmeir C, Dujardin JC, Colebunders R, Kestens L, D'Alessandro U 2006b. HIV-1 immune suppression and antimalarial treatment outcome in Zambian adults with uncomplicated malaria. J Infect Dis 194: 917-925.

Whitworth J, Morgan D, Quigley M, Smith A, Mayanja B, Eotu H, Omoding N, Okongo M, Malamba S, Ojwiya A 2000. Effect of HIV-1 and increasing immunosuppression on malaria parasitaemia and clinical episodes in adults in rural Uganda: a cohort study. Lancet 356: 1051-1056.

Whitworth JA, Hewitt KA 2005. Effect of malaria on HIV-1 progression and transmission. Lancet 365: 196-197.

WHO - World Health Organization 2000. Communicable diseases cluster 2000. Trans R Soc Trop Med Hyg 94 (Suppl 1): S1-S90.

WHO - World Health Organization 2011. World malaria Report 2011. Availablefrom:whqlibdoc.who.int/publications/2010/9789241564106 eng.pdf $>$.

Worku S, Björkman A, Troye-Blomberg M, Jemaneh L, Färnert A, Christensson B 1997. Lymphocyte activation and subset redistribution in the peripheral blood in acute malaria illness: distinct gammadelta $^{+} \mathrm{T}$ cell patterns in Plasmodium falciparum and $P$. vivax infections. Clin Exp Immunol 108: 34-41. 